\title{
BOLSA CHICA WETLANDS RESTORATION INLET DESIGN
}

\author{
Weixia $\operatorname{Jin}^{1}$ and Michael McCarthy ${ }^{1}$
}

\begin{abstract}
Bolsa Chica Wetlands is one of a few recently restored large wetlands in Southern California of the United States. The project required restoration of tidal flooding of some isolated wetlands while minimizing impacts to the shoreline adjacent to the new inlet and maintenance costs, preserving endangered species on site, and maintaining oil field operations along the periphery of the project. The project created a direct connection to the ocean through wetland basins that included a full tidal basin, muted tidal basins and seasonal ponds linked by a series of ocean jetties, levees, water control structures, culverts, and channels. The inlet is a key project feature and has been the focus of numerous technical studies and numerical modeling tasks. As part of theses analyses, a pre-filled ebb bar was designed and about 1 million cubic yards of clean sand from the lowlands dredging was placed offshore to minimize the anticipated impacts of the inlet opening to the shoreline. This paper presents the inlet location selection, inlet and wetland hydrodynamics, inlet dimension optimization, inlet stability analyses, and jettied inlet entrance design. It also discusses findings of comparison between model predictions and field measurements of tidal elevations and sediment accumulations in the wetland basin since the completion of the project in August 2006. This project received the first Project Excellence Award from COPRI (Coasts, Oceans, Ports and Rivers Institute) of the American Society of Civil Engineers in 2008.
\end{abstract}

Keywords: Bolsa Chica Wetlands, Tidal Inlet, Inlet Stability, Inlet Design, Jetty Design, Flood Shoal, Ebb Bar, and Wetland Restoration

\section{INTRODUCTION}

Bolsa Chica Wetlands is one of few recently restored large environmental restoration projects in Southern California of the United States. The project is located in West Coast of United States, in the City of Huntington Beach about 30 miles southeast of Los Angeles as shown in Figure 1. It is adjacent to a very popular state beach in Southern California.

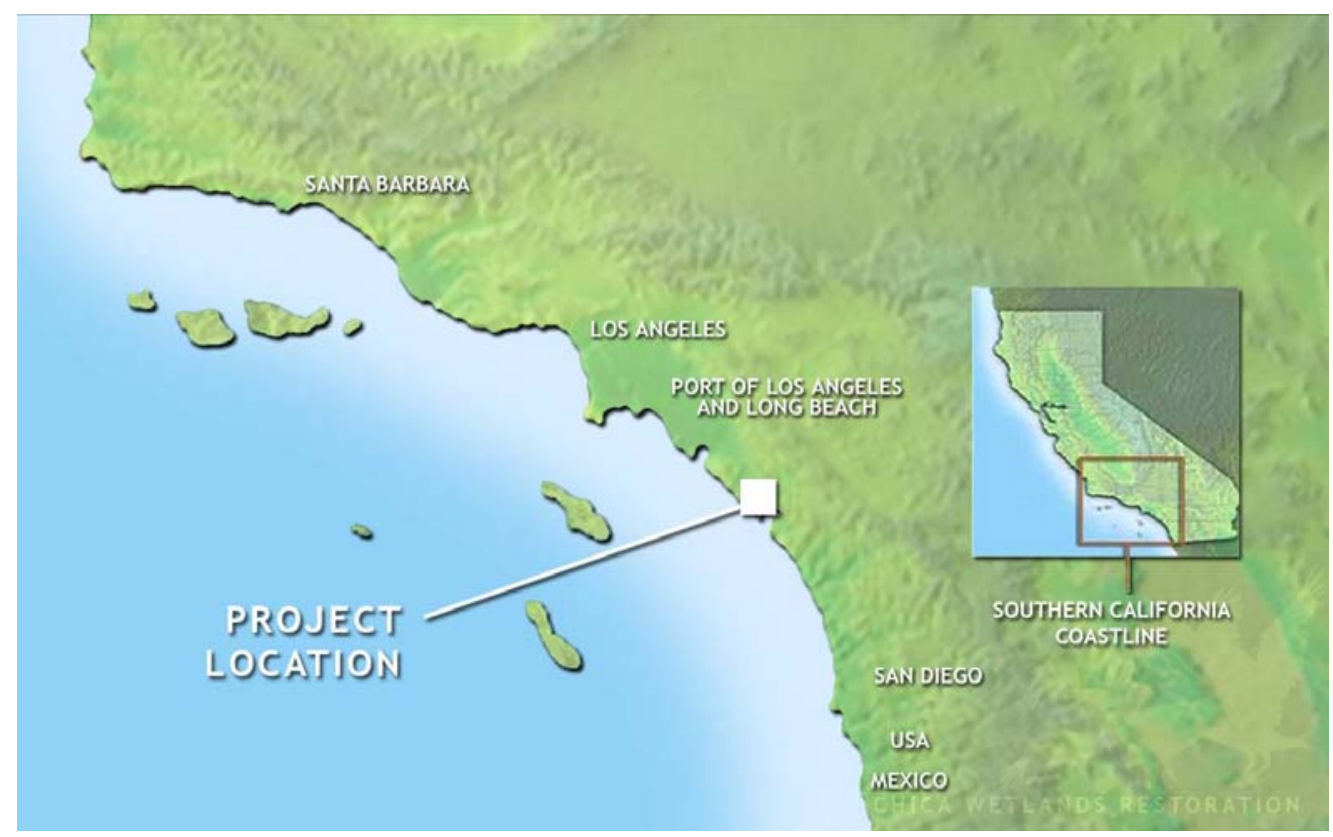

\section{Figure 1. Project Vicinity Map}

Bolsa Chica Wetlands is a 1200 -acre site that was a relic wetland, once connected to the Pacific Ocean by a tidal inlet. The inlet was closed by a duck hunting club in 1899 and oil was discovered on the site in 1925. Since then, the site has been an oil field. The impacts of these two events resulted in seriously degraded remnant wetlands within an active oil field. In 1996, eight California state and United States federal agencies and the Ports of Long Beach and Los Angeles entered into an

\footnotetext{
${ }^{1}$ Moffatt \& Nichol, 3780 Kilroy Airport Way, Suite 600, Long Beach, CA 90806, USA
} 
interagency agreement to acquire and restore the lowlands. Funding for the project came largely from the ports in return for mitigation credits to offset their future landfill construction. The overall project cost was nearly 150 million U.S. dollars. The construction started in the fall of 2004, and was completed in the fall of 2006 as scheduled, when the inlet was un-plugged and Bolsa Chica Wetlands was reconnected to the ocean after more than a century of separation.

The objective of the restoration project was to restore tidal flushing in the wetland basins while preserving existing endangered species on site, maintaining oil field operations along the periphery, eliminating significant impacts to the adjacent shoreline, and minimizing the future maintenance cost.

The restored project, referred to as Phase I, included construction of a new tidal inlet at the south end of Bolsa Chica State Beach to provide tidal exchange to the Full Tidal Basin (FTB) as shown in Figure 2. The inlet is stabilized in-place by stone jetties, with a new bridge on the Pacific Coast Highway (PCH) and a dedicated oil service bridge to allow access to a portion of the still active oil field. The inlet channel width is 310 feet at MSL and 360 feet at the levee crest. The levee crest elevation is at +13.0 feet and the inlet depth is -5 feet MSL. The jetties extend seaward from the PCH to the 0.0 feet Mean Lower Low Water (MLLW) bathymetric contour at the beach, which is -2.8 feet MSL. The Phase I wetlands consist of the FTB and Muted Tidal Basins (MTBs). The FTB connects to the ocean with the tidal inlet and it receives full ocean tide exchange, and is deepened to -6.8 feet MSL. Shallow shelves are created along the perimeter of the FTB to provide mudflats and intertidal areas. Levees are constructed around the basin to contain the tide. The MTBs, located north of the FTB, are connected to the FTB with three tidal control structures. Each tidal control structure consists of one self-regulated tidal gate, one sluice gate and multiple flap gates. The self-regulated tidal gate and the sluice gate control the inflow from the FTB to the MTBs during high tides, and the flap gates allow water to drain back to the FTB during the low tides.

The phase II project proposes the creation of the Future Full Tidal Basin (FFTB) in the northeast portion of the site when oil operations cease, assumed to be sometime in the next 20 years. This basin is proposed to be connected to the FTB with an open channel by breaching the levee. Little or no grading improvements are envisioned in the FFTB, other than breaching or removing existing oil roads, and breaching some existing levees to promote the tidal circulation. The potential FFTB development was considered in both design and analyses of the tidal inlet. Seasonal ponds will exist at their current location, and Inner Bolsa Bay (IBB) successfully restored in early 90s and the upland area of Rabbit Island will remain unchanged.

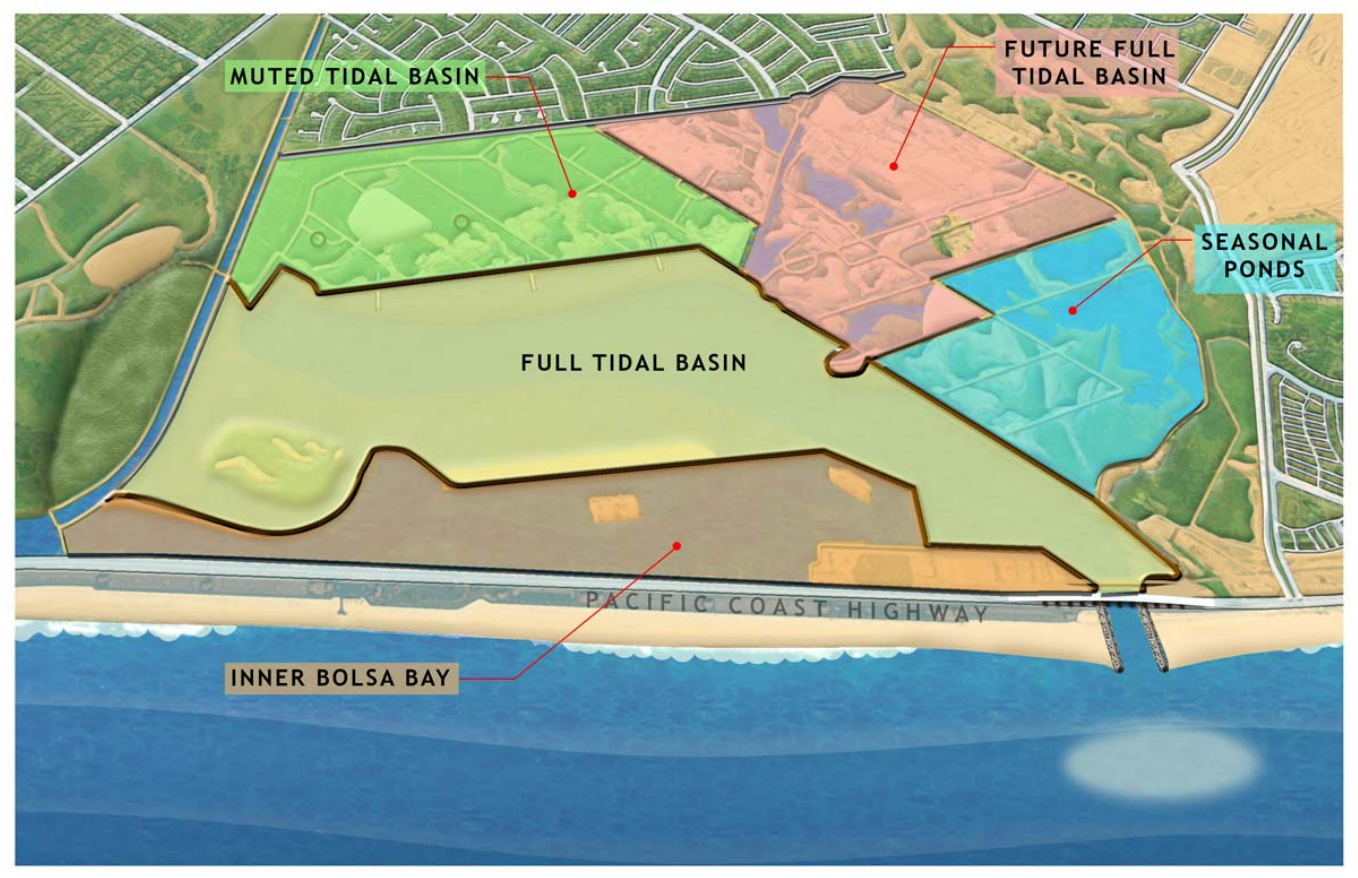

Figure 2. Project Location Map 


\section{INLET LOCATION SELECTION}

During the preliminary engineering studies (M\&N 1999), eight alternatives were developed and analyzed in support of the environmental review process. Some of them considered the possible flood flow diversion from a flood control channel located northeast corner of the FTB. Three inlet locations shown in Figure 3 were considered, but the southernmost one shown in Figure 3 as the Concept Plan Inlet was chosen because it causes less disruption of existing beach activities and wetland resources, and it will have a least future project maintenance cost, while still providing sufficient tidal flushing to achieve project objectives. The restored project does not receive any flood flow from the flood control channel due to concerns of impacts on wetland habitats during the storm events and water quality issues related to storm water discharges in the ocean near the inlet.

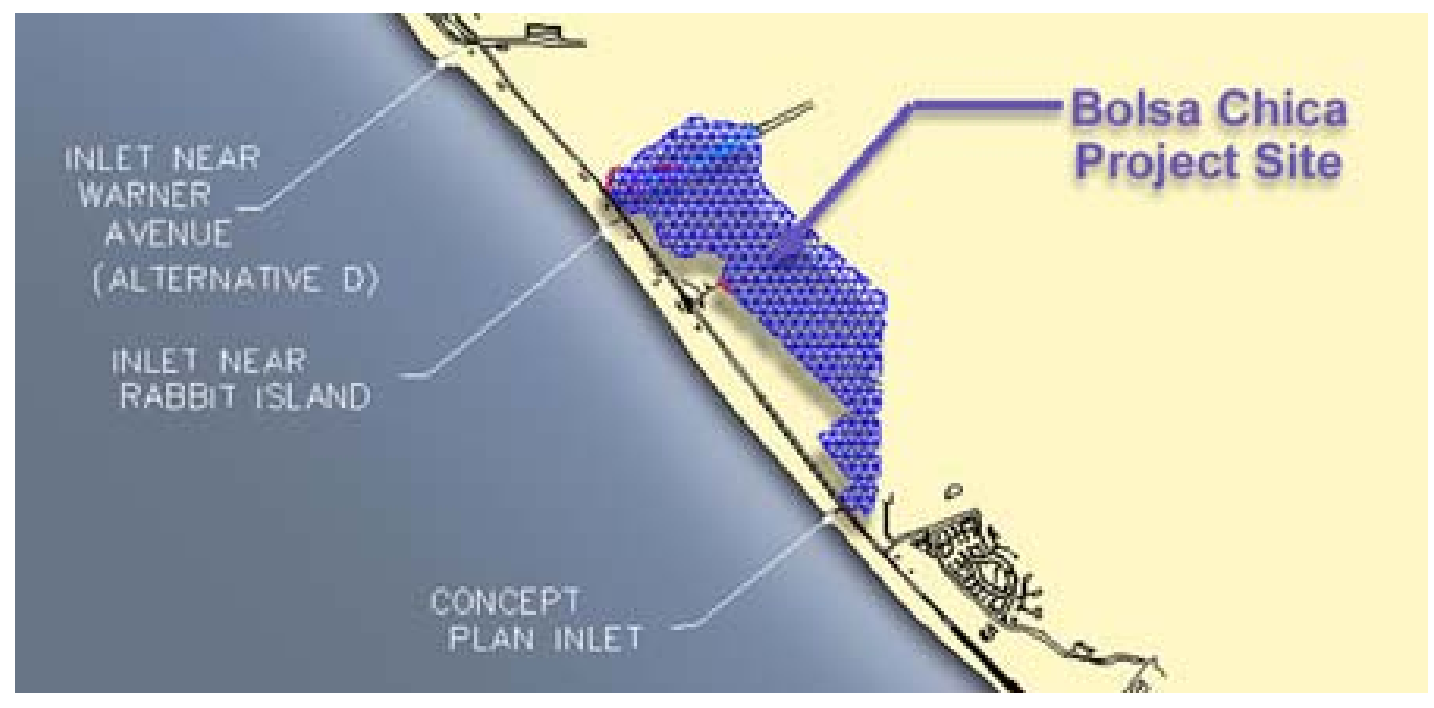

Figure 3. Inlet Location Map

\section{INLET HYDRAULICS}

The new inlet is an essential project feature and has been the focus of numerous technical studies. They included studies of hydrodynamic modeling which will be discussed in detail, flood and ebb shoaling, resultant tidal muting, changes to shoreline position, water quality effects and maintenance dredging. The inlet dimensions affect the shoaling rate in the wetland basins. The wider and shorter the inlet the higher the shoaling rates, and more frequent the maintenance dredging has to be to support the desired habitats. The development of flood shoals results tidal muting and reduces tidal circulation and flushing in the wetland basins. Reduced tidal flushing could lead to poor circulation and unstable inlet. Therefore, the maintenance dredging study is an important part of the wetland design. If the inlet is too narrow and too long, the tide may be severely muted in the wetland and the wetland can't achieve the inundation frequency required to create desired wetland regime. The longer the inlet and jetties the more stable the inlet, but long jetties would have additional negative impacts to the adjacent shoreline and beaches. The shoreline morphology study addressed the impacts of the new inlet and was also an important part of the inlet dimension optimization. Details of these studies are included in the preliminary engineering studies of Bolsa Chica wetlands (M\&N 1999).

The two-dimensional, vertically averaged finite element hydrodynamic model (RMA2), developed by the U.S. Army Corps of Engineers (USACE), was applied in tidal and flood hydrodynamic modeling. This model is capable of simulating tidal wetting and drying of marsh and intertidal areas of the estuarine system. The purposes of the RMA2 modeling was to evaluate the wetlands hydraulics by predicting the tidal ranges and tidal inundation frequency in the proposed wetlands for habitat design; to predict the potential maximum water level for flood protection and levee design along the wetland perimeters; to optimize the tidal inlet dimensions; to estimate the tidal inlet velocities for inlet stability analyses; and to generate the flow fields to drive the water quality model RMA4 and sediment transport model SED2D. 
RMA2 Model Setup

Setup for the tidal hydraulic model for the selected alternative included determination of the modeling area, bathymetry, wetland habitat area, finite element mesh, and boundary conditions.

Modeling Area. The modeling area covers the FTB and a relatively large nearshore ocean area for Phase I. Phase II includes the addition of the FFTB as shown in Figure 4. There are several factors used to decide the aerial extent of the modeling area. First, it is desirable to extend the mesh open boundaries to areas which are sufficiently distant from the proposed areas of change so as to be unaffected by that change. The ocean boundary (at an average contour elevation of -85 feet MSL) is approximately four miles from the shoreline. The side boundaries are approximately two miles northwest and southeast from the project site. Additionally, mesh boundaries must be located along sections where conditions can reasonably be measured and described to the model. Finally, mesh boundaries can be extended to an area where conditions have been previously collected to eliminate the need to interpolate between the boundary conditions from other locations. The entire modeling area is approximately 24 square miles.

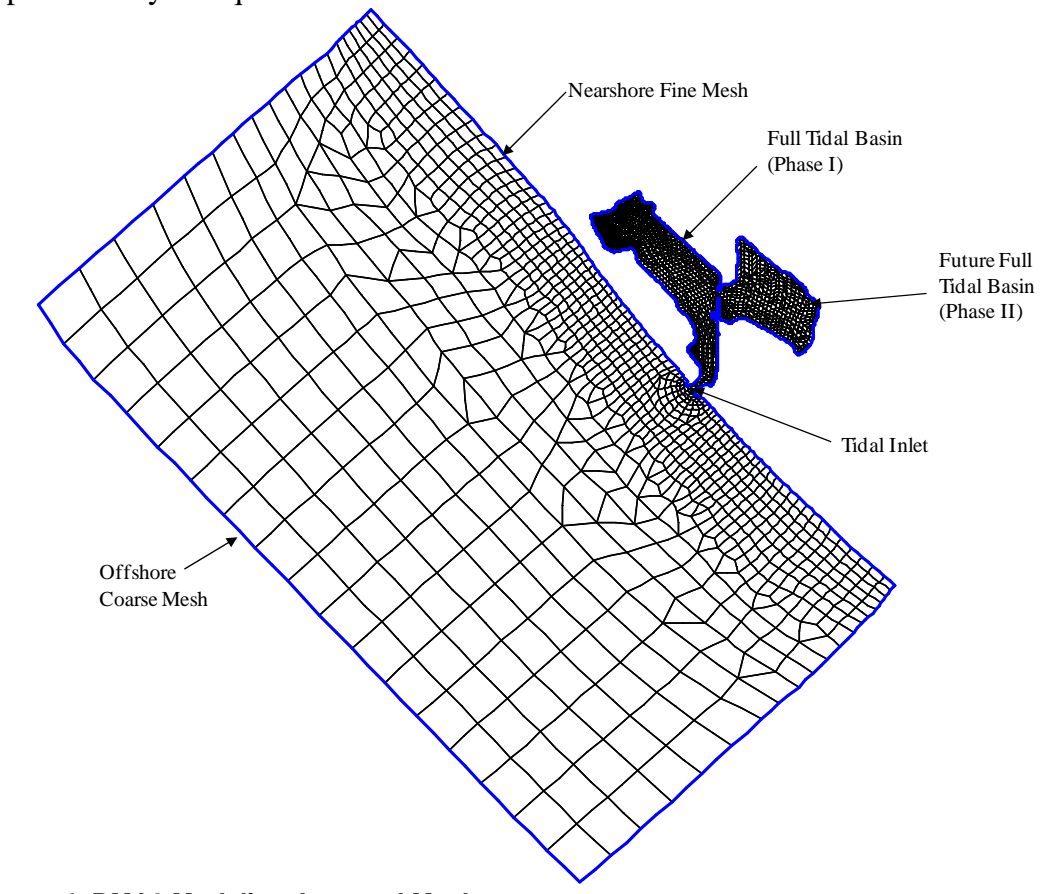

Figure 4. RMA2 Modeling Area and Mesh

Wetland Habitat Area Based on the Grading Plan. The wetland storage area and tidal range specify the tidal prism (volume of seawater exchanged during one mean tidal cycle). The inundation curve created from hydrodynamic modeling results dictates the wetland areas for each habitat type. The wetland areas created and the distribution of habitats can be determined through consideration of the tidal range, storage area and inundation curves. The created habitat areas for the selected alternative under the post-construction condition are provided in Table 1 as compared to the Memorandum of Agreement (MOA). Phase II includes the addition of the FFTB. The FFTB grading includes removal of some of the existing levees in order to promote tidal circulation and to increase the tidal range. No MOA requirements were specified for the Phase II wetland areas.

\begin{tabular}{|c|c|c|c|}
\hline \multirow[t]{2}{*}{ Habitat Area Description } & \multicolumn{2}{|c|}{ Area (acres) $/(\%$ of total project area) } & \multirow{2}{*}{$\begin{array}{l}\text { MOA Specifications } \\
\text { (Phase I only1) }\end{array}$} \\
\hline & Phase I & Phase II & \\
\hline Subtidal Area (below -6 ft MSL) & $175.5(47.8 \%)$ & $175.5(28.3 \%)$ & $175.0(50 \%)$ \\
\hline Intertidal Area (-6 to $-0.3 \mathrm{ft} \mathrm{MSL})$ & $122.6(33.5 \%)$ & $314.8(50.8 \%)$ & $122.5(35 \%)$ \\
\hline High Intertidal (-0.3 to +2.7 ft MSL) & $49.5(13.5 \%)$ & $110.1(17.8 \%)$ & $52.5 \quad(15 \%)$ \\
\hline Above Tidal (higher than $+2.7 \mathrm{ft} \mathrm{MSL}$ ) & $18.9(5.2 \%)$ & $19.2(3.1 \%)$ & Not Specified \\
\hline $\begin{array}{l}\text { Total Project Wetland Area } \\
(-6 \text { to }+2.7 \mathrm{ft} \mathrm{MSL})\end{array}$ & $347.6(94.8 \%)$ & $600.3(96.9 \%)$ & 350.0 \\
\hline Total Project Area (-6 to $+5.5 \mathrm{ft} \mathrm{MSL})$ & 366.5 & 619.5 & Not Specified \\
\hline
\end{tabular}


Finite Element Mesh. The RMA2 model implemented herein requires that the modeling area be represented by a network of nodal points and elements, points defined by coordinates in the horizontal plane and water depth, and areas made up by connecting these adjacent points, respectively. Nodes can be connected to form 1- and 2-D elements, having from two to four nodes. The resulting nodal/element network is commonly called a finite element mesh and provides a computerized representation of the estuarial geometry and bathymetry. The two most important aspects to consider when designing a finite element mesh are (1) determining the level of detail necessary to adequately represent the estuary, and (2) determining the extent or coverage of the mesh. The model described in this section is numerically robust and capable of simulating tidal elevations and flows with reasonable resolution. Accordingly, the bathymetric features of the estuary generally dictate the level of detail appropriate for each mesh. Figure 4 shows the finite element mesh, consisting of 2833 elements and 8636 nodes, for the Phase II project condition. Under the Phase I conditions, the mesh of the FFTB area is removed and the remaining mesh includes 2293 elements and 7036 nodes.

Boundary Conditions. Since there are no tide stations at Bolsa Chica, the nearest Los Angeles Outer Harbor (LAOH) gage (NOAA Station 941660) was used for the project site. The NOAA gage is located immediately adjacent to the open ocean and represents the ocean tidal conditions. The diurnal tide range is approximately 5.5 feet (MLLW to MHHW) and MSL is at +2.8 feet MLLW. The Tidal Epoch Analysis (TEA) tidal series was applied at the model offshore open boundaries for wetland and inlet hydrodynamic modeling. The TEA tide is a synthetic 14-day tidal series developed statistically to match the cumulative distribution of water levels over a 19-year tidal epoch (1960-1978) as performing simulations using 19 years of water level data for each computer run is impractical. The TEA tide includes both spring and neap tidal ranges. By using the TEA tide for hydrodynamic modeling, longterm tidal variations can be modeled with relatively small computation times. The hydraulic modeling results predict long-term water level distribution and tidal inlet hydraulics. The selected alternative is the no flood flow diversion alternative, so there is no flow boundary.

\section{Hydrodynamic Modeling Results}

Modeling simulations were performed with the TEA tidal series applied at the model offshore boundaries. The modeling parameters of the roughness coefficients, eddy viscosity and dispersion coefficients were assigned based on the calibration results and the literature review for similar bay and coastal waters (M\&N, 1999). Hydraulic modeling results under Phase I project condition are shown in Figure 5. The tide series shown as ocean is the TEA tidal series. The results show that the FTB experiences the same high tides as that in the ocean; however, the low tides are muted. The highest muting is during the spring low tide. The spring low tide is truncated about $0.9 \mathrm{ft}$, and the time lag of the spring low tide is about 1.5 hours. The time lag for the spring high tide is only 0.2 hours.

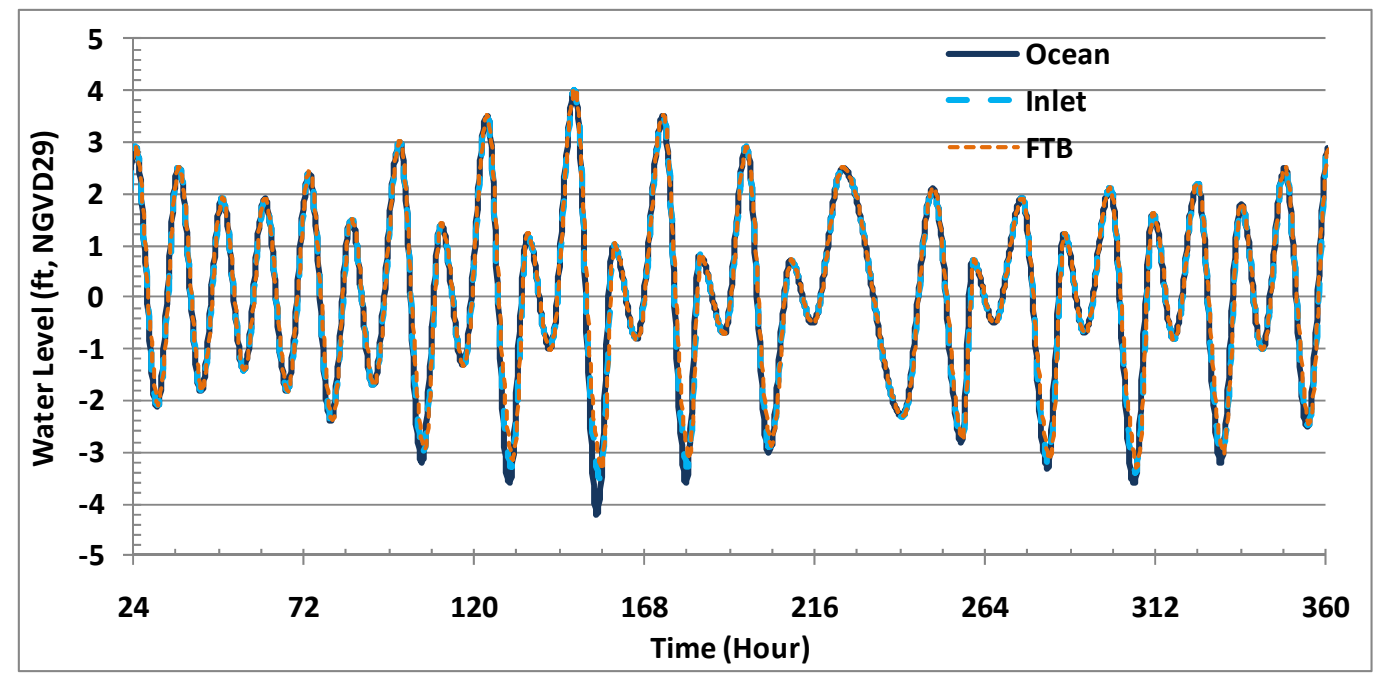

Figure 5. Water Levels under TEA Tide Series 
The full ocean tide range is difficult to obtain due to the inability to convey flow through the wetlands at low tide. This inability to convey flow stems from a combination of high friction and relatively small cross-sectional area in the wetland channel, and the shallow inlet. The low tide will be muted further under the Phase II project condition since there is a tendency for a decrease in tidal range as the wetland area increases. The degree of muting will depend on grading and the resultant storage capacity of the FFTB. The reduction in tidal range occurs as it becomes more difficult to fill/empty larger bays through the same tidal inlet and/or network of wetland channels. The tidal range could be increased either by deepening the inlet and/or by widening the channel connecting the inlet and wetland areas in order to better convey flows. This matter is discussed further in the next section.

Tidal flow velocities vary within the wetlands and reach a peak in the inlet. The magnitude and duration of inlet velocities are important to inlet stability. Tidal velocities at the center of the inlet under the Phase I Project are shown in Figure 6. The peak flood velocity is higher than the peak ebb velocity under the Phase I project. However, both peak ebb and flood velocity exceeded 3.28 fps threshold for inlet stability. Additional discussion of the inlet velocities is provided in the inlet stability section.

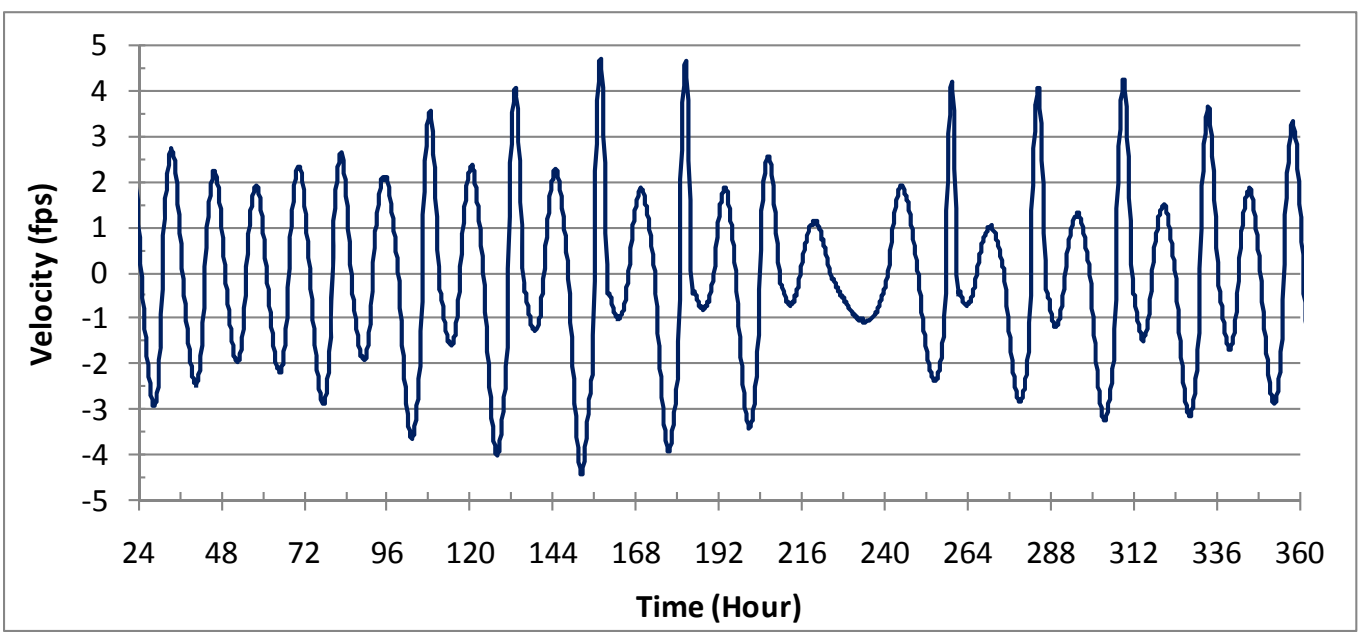

Figure 6. Tidal Inlet Velocity under TEA tide Series

\section{Sensitivity of Tidal Inlet Dimensions}

The inlet geometry for the Phase I project was varied in order to understand the impact of inlet dimensions on the basin tidal ranges. The sensitivity analysis shows that the wetland low tide is truncated relative to the ocean principally because of the limited inlet depth as detailed in Table 2. While fixing the inlet depth at $-5 \mathrm{ft}$ MSL, the tidal range only increases 0.4 feet when the inlet width increases from 310 feet to 450 feet. The full tidal range in the wetland system occurs, however, if the inlet depth is increased to -6.8 feet MSL while fixing the inlet width at $310 \mathrm{ft}$. This finding demonstrates that the inlet geometry, as distinct from the wetland geometry, controls the wetland tidal ranges.

\begin{tabular}{|c|c|c|c|c|c|c|}
\hline \multirow{2}{*}{$\begin{array}{l}\text { Project } \\
\text { Phase }\end{array}$} & \multicolumn{2}{|c|}{ Inlet Dimensions at MSL } & \multicolumn{2}{|c|}{ Wetland Tides(MSL, feet) } & \multicolumn{2}{|c|}{ Inlet Velocity (fps) } \\
\hline & Width (feet) & Depth (feet) & High Tide & Low Tide & Peak Flood & Peak Ebb \\
\hline \multirow{7}{*}{ I } & \multirow{3}{*}{350} & -5.0 & 4.0 & -3.5 & 4.46 & -4.08 \\
\hline & & -5.5 & 4.0 & -3.8 & 4.13 & -3.84 \\
\hline & & -6.8 & 4.0 & -4.15 & 3.11 & -3.13 \\
\hline & 310 & \multirow{4}{*}{-5.0} & 4.0 & -3.3 & 4.72 & -4.42 \\
\hline & 350 & & 4.0 & -3.5 & 4.46 & -4.08 \\
\hline & 400 & & 4.0 & -3.6 & 4.04 & -3.62 \\
\hline & 450 & & 4.0 & -3.7 & 3.39 & -3.31 \\
\hline II & 310 & -5.0 & 4.0 & -3.1 & 5.80 & -6.70 \\
\hline \multicolumn{3}{|c|}{ Ocean as tidal reference } & 4.0 & -4.2 & $\mathrm{~N} / \mathrm{A}$ & N/A \\
\hline
\end{tabular}




\section{INLET DIMENSIONS}

The tidal inlet dimensions were designed to achieve the habitat restoration objectives in the wetlands and a stable tidal inlet. Design goals include minimization of bridge and jetty construction costs, inlet maintenance costs, and impacts to littoral processes. Key considerations in the final selection of inlet dimensions included:

Habitat Restoration Objectives. The inlet is deep and wide enough such that a full tidal range and the desired frequency of habitat inundations can be achieved in the full tidal basin. Also, it would be large enough to pass tidal flows sufficient to permit the future restoration of another 252 acres of FFTB to tidal influence.

Hydraulic Stability of Inlet. The tidal inlet must narrow enough to maintain sufficient tidal ebb velocities at the inlet to suspend and carry the sediment away from the sandy inlet to maintain a stable inlet against closure. The length of jetties must be long enough to preclude excessive sediment migration from beach into the inlet, causing inlet closure and ultimately increase the inlet maintenance costs.

Bridge Construction Costs. There is a direct economic benefit to minimizing the inlet width dimension in order to reduce the length of the $\mathrm{PCH}$ and oil service bridges and associated bridge construction costs.

Impacts to Littoral Process. The tidal inlet is deep enough such that the low tide in the tidal basin would not be muted, but not too deep to require longer jetties to maintain an open inlet. Longer jetties would result impacts to littoral processes and increase the jetty costs.

The final design inlet width was $310 \mathrm{ft}$ at MSL and $360 \mathrm{ft}$ at the jetty crest, which is wide enough to accommodate the Phase II FFTB development, but is not too wide to result in an unstable inlet under the Phase I project condition before the FFTB development. The inlet depth is $-5 \mathrm{ft}$ MSL, which is shallower than the grading of the wetland basin at $-6.8 \mathrm{ft}$, so fish will not be stranded in the FTB under the extreme low tidal condition, but deep enough to create the desired habitat regimes under the postconstruction conditions.

\section{INLET STABILITY ANALYSES}

There are two types of inlet stability: (a) stability against closure, and (b) stability against migration of the inlet. The latter is not a concern for the Bolsa Chica Inlet because the inlet is stabilized with two jetties. Therefore, the emphasis of the analyses was on the stability against closure.

Inlet stability analyses were conducted for both Phase I and II project conditions. Escoffier (1940), O’Brien (1969), Bruun (1978) and many others have developed methodologies that can be used to assess the stability of a tidal inlet against closure. Each of these authors advance the argument that inlet stability depends on the balance between tidal flows, which tend to keep the channel open, and littoral drift, which tends to close the inlet.

Inlet stability analyses focus on the equilibrium between the inlet cross-sectional area and inlet hydrodynamics. The controlling variables are the actual maximum tidal velocity (or shear stress) in the tidal inlet, and the equilibrium tidal velocity (or shear stress) that is required to prevent deposition of sediments carried into the inlet by longshore currents. According to Bruun (1978), Van de Kreeke (1984), and others, the equilibrium velocity for most inlets is $3.28 \mathrm{fps}$. When the actual velocity equals the equilibrium velocity the inlet is in equilibrium. When the actual velocity exceeds the equilibrium velocity then the inlet is in a scouring or erosion mode, and conversely, when the actual velocity is lower than the equilibrium velocity the inlet is in a shoaling or depositional mode.

The equilibrium velocity, among other factors, depends on the magnitude and direction of longshore sediment transport rates. Specifically, the equilibrium velocity increases with littoral transport rate. The following three methods are widely used, and were applied to the Bolsa Chica Inlet:

- Inlet Channel Cross-sectional Area versus Tidal Prism

- Maximum Velocity in the Inlet Channel

- $\quad$ Littoral Drift - Tidal Prism Method

The tidal flow is the main factor in keeping an inlet open and is represented by the tidal prism. Different methods for inlet stability analyses use different tidal prisms, i.e., spring, neap, MHHWMLLW or mean. The post-construction tidal prisms used in the following analyses are summarized in Table 3. The spring low tides are muted, and are $-3.3 \mathrm{ft}$ under phase I project condition, and $-3.1 \mathrm{ft}$ under the phase II project condition. 


\begin{tabular}{|c|c|c|c|c|c|}
\hline \multirow[b]{2}{*}{ Phase } & \multirow[b]{2}{*}{$\begin{array}{l}\text { Water Surface Area, } \\
A_{B},(\text { acres at MSL) }\end{array}$} & \multicolumn{4}{|c|}{ Tidal Prism (Million $\mathrm{ft}^{3}$ ) } \\
\hline & & $\begin{array}{l}\text { Spring Tide } \\
\left(4.0 \text { to }-^{*} \mathrm{ft}\right)\end{array}$ & $\begin{array}{l}\text { MHHW-MLLW } \\
(2.72 \text { to }-2.80 \mathrm{ft})\end{array}$ & $\begin{array}{l}\text { Mean Tide } \\
\text { (1.97 to }-1.85 \mathrm{ft} \text { ) }\end{array}$ & $\begin{array}{l}\text { Neap Tide } \\
(1.44 \text { to }-1.40 \mathrm{ft})\end{array}$ \\
\hline I & 296 & 96.4 & 70.5 & 49.5 & 36.7 \\
\hline II & 512 & 158 & 117 & 83.9 & 62.7 \\
\hline
\end{tabular}

Inlet Channel Cross-Section versus Tidal Prism. O’Brien (1931 and 1969) examined a number of tidal inlets and determined that the cross-sectional flow areas of stable inlets are a strong function of tidal prism. Building on the work of O'Brien, Jarrett (1976) developed two families of curves, one for natural and one for jettied inlets. Jarrett's relationships derived from inlets in the Pacific Ocean are given below:

$$
\begin{aligned}
& \mathrm{A}_{\text {c-equil }}=1.91 \times 10^{-6} \mathrm{P}^{1.1} \text { (natural) } \\
& \mathrm{A}_{\text {c-equil }}=5.28 \times 10^{-4} \mathrm{P}^{0.85} \text { (jettied) }
\end{aligned}
$$

where $A_{c-e q u i l}$ is the equilibrium inlet channel cross-sectional area and $\mathrm{P}$ is the spring tidal prism of the wetlands. The Bolsa Chica Inlet jetties will extend to the MLLW line and are much shorter than most inlet jetties. Therefore, the Bolsa Chica Inlet is expected to behave somewhere between a natural and jettied inlet. The percent difference between the designed cross-sectional area, $\mathrm{A}_{\mathrm{c} \text {-design }}$, and the calculated equilibrium area, $\mathrm{A}_{\mathrm{c}-\mathrm{Equi}}$, is obtained as:

$$
\text { Percent Difference }=\left(\mathrm{A}_{\mathrm{c}-\text { Equil }}-\mathrm{A}_{\mathrm{c}-\text { Design }}\right) / \mathrm{A}_{\mathrm{c}_{-} \text {Design }} \mathrm{x} 100 \%
$$

The $A_{c \text {-design, }}$ area below MSL, for Bolsa Chica inlet is approximately 1,471 square feet $\left(\mathrm{ft}^{2}\right)$. The equilibrium inlet areas and percentage of deviation are summarized in Table 4.

\begin{tabular}{|l|l|l|l|l|}
\hline \multicolumn{2}{|l|}{ Table 4. Equilibrium Inlet Areas And Percent Difference From The Design Inlet } \\
\hline \multirow{2}{*}{ Phase } & Natural Inlet & Inlet with Jetties \\
\cline { 2 - 5 } & $\mathrm{A}_{\mathrm{C}_{\text {Equil }}\left(\mathrm{ft}^{2}\right)}$ & Change (\%) & $\mathrm{A}_{\mathrm{C}_{\text {Equil }}}\left(\mathrm{ft}^{2}\right)$ & Change $(\%)$ \\
\hline $\mathrm{I}$ & 1157 & -21 & 3229 & 120 \\
\hline $\mathrm{II}$ & 1993 & 36 & 4915 & 234 \\
\hline
\end{tabular}

Under the Phase I project, the $\mathrm{A}_{\mathrm{c} \text {-Equil }}$ is smaller than $\mathrm{A}_{\mathrm{c} \text {-design }}$ under the natural inlet without jetty condition. The inlet is too big to be stable for without jetty condition. In other words, the tidal prism is not big enough to maintain a stable inlet under the natural inlet condition. Deposition will be the main inlet stability concern. The inlet cross-sectional area will become smaller and smaller over time and lead to a potential closure. However, under the jettied condition, the $\mathrm{A}_{\mathrm{c} \text {-Equil }}$ is bigger than $\mathrm{A}_{\mathrm{c} \text {-design }}$ and the inlet will be stable under the normal condition. Therefore, jetties are required to maintain a stable inlet.

Under the Phase II project with the increased tidal prism, the $\mathrm{A}_{\mathrm{c} \text {-Equil }}$ is bigger than $\mathrm{A}_{\mathrm{c} \text {-design }}$ under both the with and without jetty conditions, therefore, the inlet will be more stable under the Phase II project condition, and erosion and not deposition will be the main inlet stability concern.

The tidal inlet channel is a dynamic system and the equilibrium cross-sectional area indicates the expected long-term condition. Significant variations are to be expected as a result of changes in tidal condition, i.e., between spring and neap tides.

Maximum Velocity at the Inlet Channel. The flow conditions in the inlet are also used to assess the inlet stability. One of the simplest methods is to consider the peak ebb flow velocity. In order to maintain an open inlet, the peak ebb velocity must be sufficient to move sediment deposited within this area by littoral and cross-shore sediment transport. A general approximated criterion developed by Byrne, et al. (1980) for maintaining an open ocean inlet is:

$$
\mathrm{U}_{\text {crit }} \approx 3.28 \pm 0.5 \mathrm{fps}
$$

where $U_{\text {crit }}$ is the critical maximum ebb flow velocity in the inlet. When the maximum ebb flow velocity is greater than $U_{\text {crit }}$, the inlet is stable. Based on the hydraulic modeling results, the maximum ebb velocities shown in Table 2 are much higher than $U_{\text {crit }}$ under both project phase conditions. Therefore, the inlet is stable based on the ebb velocity criterion.

Littoral Drift - Tidal Prism Method. Littoral transport conveys beach sediment into the inlet; the greater the transport rate, the more sediment is conveyed to the inlet area, creating the possibility of 
inlet closure. Bruun (1978) examined inlet stability as a function of the spring tide prism in cubic yards, $\mathrm{P}_{\text {spring }}$, and annual gross littoral drift, $\mathrm{M}_{\mathrm{TOT}}$, as detailed in Table 5.

\begin{tabular}{|l|l|}
\hline \multicolumn{2}{|l|}{ Table 5. Relationships Among Longshore Transport, Tidal Prism And Inlet Stability } \\
\hline Ratio & Stability \\
\hline $\mathrm{P}_{\text {spring }} / \mathrm{M}_{\text {TOT }}>150$ & Conditions are good, very good flushing and minor bar formation \\
\hline $150>\mathrm{P}_{\text {spring }} / \mathrm{M}_{\text {TOT }}>100$ & Less good condition, and offshore bar formation is more pronounced \\
\hline $100>\mathrm{P}_{\text {spring }} / \mathrm{M}_{\text {TOT }}>50$ & Rather large bar by entrance, but usually a channel through the bar \\
\hline $50>\mathrm{P}_{\text {spring }} / \mathrm{M}_{\text {TOT }}>20$ & Typical "bar-bypass" - gets flushed by the increased water discharge during storms \\
\hline $20>\mathrm{P}_{\text {spring }} / \mathrm{M}_{\text {TOT }}$ & Very unstable inlets, mainly just overflow channels \\
\hline
\end{tabular}

The spring tidal prisms are shown in Table 3. The calculated ratio of $\mathrm{P}_{\text {spring }} / \mathrm{M}_{\mathrm{TOT}}$ for average and severe annual gross longshore sediment transport rates is summarized in Table 6. Under the average longshore transport rate condition, the inlet is not stable under Phase I and is stable under Phase II. Under a severe winter with high longshore sediment transport rate condition, the inlet is not stable under both phase conditions. However, Brunn pointed out that jetties can increase the sediment bypass of the inlet by 20 to 30 percent; hence, reduce sediment inflow into the lagoon and improve the inlet stability. This analysis indicates that jetties are required to maintain a stable inlet in Bolsa Chica.

\begin{tabular}{|l|l|l|}
\hline \multicolumn{3}{|l|}{ Table 6. Ratios of $\mathbf{P}_{\text {spring }} / \mathbf{M}_{\text {TOT }}$} \\
\hline Phase & $\mathrm{M}_{\text {TOT, average }}=300,000 \mathrm{cy} / \mathrm{yr}$ & $\mathrm{M}_{\text {TOT, severe }}=1,000,000 \mathrm{cy} / \mathrm{yr}$ \\
\hline $\mathrm{I}$ & 12 & 4 \\
\hline $\mathrm{II}$ & 20 & 6 \\
\hline
\end{tabular}

Conclusions. Three semi-empirical methods with differing parameters with respect to inlet stability were applied to Bolsa Chica Inlet. These stability analyses were based on the immediate postconstruction conditions. The conclusions derived from applying these methods to the Bolsa Chica Inlet for inlet stability are as follows:

- All of the methods found that the inlet is more stable in Phase II than Phase I.

- Two methods considered impacts of jetties and indicated that jetties are required to maintain a stable inlet.

- All methods except the Bruun's found that the inlet is stable and open in both phases with jetties. The Bruun's method indicates that the inlet is not stable during a severe winter with a high longshore sediment transport rate.

- All methods provide a general and long-term prediction of the inlet stability. During severe events, the inlet may be temporarily closed and may need to be manually reopened.

\section{JETTIED INLET DESIGN}

The purpose of the jetties is to fix the inlet location and maintain the depth of the inlet through the beach, and to remain stable during extreme storm events. In general, the goal of the design process for the inlet jetties and adjacent coastal shore protection is to develop a stable and economic design with minimal impacts on the environment. The design should be practical and relatively easy to construct and maintain. The inlet design process includes determining the design water level and wave conditions at the inlet, and sizing armor rocks for jetties.

\section{Design Water Level}

The primary factors that affect water levels in the Southern California Bight are: astronomical tides, storm surge, El Nino-Southern Oscillation (ENSO) events, long-term changes in sea level, and wave setup. Each of these factors is discussed in the following sub-sections.

Astronomical Tides. Astronomical tides in the Southern California Bight are of the mixed, semidiurnal type, with two highs and two lows of unequal height occurring each lunar day as shown in Figure 5 (the duration of which averages 24.4 hours). The largest water level excursion typically occurs as the tide falls from higher high to lower low water, a process that generally requires 7 to 8 hours (USACE 1993). The unusually high sea level recorded on January 27, 1983 was due to a combination of higher than normal mixed layer temperature associated with a strong, 2-year El Nino, storm surge due to low atmospheric pressure and persistent onshore winds, and the cumulative effect of steady, "global” rise in relative sea level (Flick \& Cayan, 1984). Therefore, the extreme high water 
level of $5.0 \mathrm{ft}$ (MSL), which included effects of the higher than normal temperature, El Nino storm surge, and onshore wind-induced setup, was selected as the design tidal elevation.

Storm Surge. Storm surge is the superelevation of the water level that results from reduced barometric pressure (the so-called "inverted barometer effect") and wind stress during storms. Unlike the Atlantic and Gulf Coasts, where storm surges can attain high amplitudes on the relatively wide, shallow, and gentle slopes of the Continental Shelf, surges on the southern Pacific Coast are comparatively small when compared with tidal fluctuations. No additional storm surge is considered since the recorded extreme high water level has already included the storm surge.

ENSO Events. ENSO events represent global-scale climatic variations with duration of 1 to several years. They are characterized by a decrease in atmospheric pressure in the eastern tropical Pacific Ocean, a decrease in the easterly trade winds, and an increase in sea level on the west coast of North and South America. According to Flick and Badan-Dangon (1989), increased water levels resulting from ENSO events may be expected every 4 to 7 years, with 4 or 5 strong events each century. During the major ENSO event in the 1997-1998 season, monthly MSLs in the Southern California Bight were increased by up to 1 foot (Flick 1998). No additional water level increase is considered in the design since the recorded extreme high water level has already included the effect of the El Nino storm surge.

Sea Level Rise. Global sea level trends have been estimated by combining the trends at tidal stations around the world. In the last century, the worldwide sea level has risen 4 to 10 inches (Barnett, 1984; Peltier and Tushingham, 1989; and Douglas, et al. 2001), much of which has been attributed to the global warming of the last century (Gornitz et al., 1982; Meier 1984). A long-term sea level rise of 0.04 to 0.08 inches per year is documented in the record of Fort Point under Golden Gate Bridge, which is the longest continuous sea-level record for any site on the west coast of North America (USGS 1999). Based on long-term water level measurement NOAA/NOS (1997) summarized the longterm historic relative sea level rise trends at 81 stations. The "trend" representing the slope of a leastsquares line of regression through the yearly means and "error" representing the standard error of slope of the trend line at stations closest to the project site and that at the San Francisco Bay are listed in Table 7. The fact that sea level is rising is unquestionable, but scientists are not in total agreement on the rate of rise and acceleration. Studies (USEPA, 1983; IPCC 1990; and Meier et al.1990) after 1983 have focused on the sea level rise over the next century, which generally fall in the range of 2 to 7 feet by 2100. The Union of Concerned Scientists (Moser 2003) states that the Sea-level Change in California is expected to be $0.66-1 \mathrm{ft}$.

\begin{tabular}{|c|c|c|c|c|c|c|c|}
\hline Station & Name & Begin & $\begin{array}{l}\text { Total Series Used } \\
(\mathrm{yr})\end{array}$ & $\begin{array}{l}\text { Trend } \\
(\mathrm{mm} / \mathrm{yr})\end{array}$ & $\begin{array}{l}\text { Error } \\
(\mathrm{mm} / \mathrm{yr})\end{array}$ & $\begin{array}{l}\text { Trend } \\
\text { (ft/yr) }\end{array}$ & $\begin{array}{l}\text { Error } \\
\text { (ft/yr) }\end{array}$ \\
\hline 9410660 & Los Angeles, CA & 1923 & 69 & 0.84 & 0.18 & 0.0027 & 0.0006 \\
\hline 9410580 & Newport, CA & 1955 & 37 & 2.11 & 0.52 & 0.0069 & 0.0017 \\
\hline 9414290 & San Francisco, CA & 1854 & 139 & 1.39 & 0.09 & 0.0046 & 0.0003 \\
\hline
\end{tabular}

Considering the uncertainties involved in prediction of the sea level rise, a median sea level rise rate of 1 foot per century was selected for the design of Pacific Coast Highway (PCH) Bridge over the Bolsa Chica Inlet. With a design life 50 years for the project, a sea level rise of $0.50 \mathrm{ft}$ was considered in the design.

Wave Setup in the Tidal Inlet. Wave setup in the tidal inlet is less than that on the beach due to the following factors:

- Energy is being dissipated in the rock jetties, which is associated with fluid motion over the rough slope surface and within the pores of the structure;

- The tidal inlet is connected to 366.6 acres of wetlands which allows the accumulated mass due to wave motion to dissipate into the wetlands; and

- The existence of a pre-filled ebb bar during construction and a natural formed ebb bar after construction causes waves breaking further offshore, which results less wave setup in the tidal inlet.

Wave setups at the Brunswick River entrance on the East Coast of Australia about 50mi south of the Queensland/New South Wales border (Hanslow and Nielsen, 1992; Hanslow, 1996) were measured over a period of 10 years. The river entrance is regulated by rubble mound training walls (jetties). The channel width near the end of the training walls is approximately $131 \mathrm{ft}$ and the mid tide 
depth is normally 13 to $16 \mathrm{ft}$, but can be as shallow as 3 to $6 \mathrm{ft}$ on the offshore bar which experiences wave breaking even under relatively small wave conditions. The spring tide prism of the Brunswick River is approximately $169.5 \times 10^{6} \mathrm{ft}^{3}$. The measurements of super-elevation were taken from $490 \mathrm{ft}$ offshore from the end of jetties to $980 \mathrm{ft}$ upstream (landward) from the end of jetties. The results suggest that the contribution of wave setup to the super-elevation of river entrance water levels is quite small, and is less than $0.03 \mathrm{H}_{\mathrm{so}}$, where $\mathrm{H}_{\mathrm{so}}$ is the deep water significant wave height.

Water level variations at Shiribetsu River mouth (Tanaka and Lee, 2001), which is located in western part of Hokkaido, Japan and pours into Japan Sea, were measured From January 1991 to December 1998. Wave setup data were selected when the wave height was higher than $6.6 \mathrm{ft}$ and fresh water discharge smaller than $7,000 \mathrm{ft}^{3} / \mathrm{s}$. The backup water effect was significant when the fresh water discharge was higher than $7,000 \mathrm{ft}^{3} / \mathrm{s}$. The results suggest that the super-elevation of the water level above tidal elevation observed in the Shiribetsu River mouth is induced by wave setup caused by breaking wave in front of the river mouth. Wave setups measured in December 1996 when the fresh water discharges are around $7,000 \mathrm{ft}^{3} / \mathrm{s}$ suggest the following relationship between the wave setup, $\mathrm{S}_{\mathrm{w}}$, and offshore wave height:

$$
\mathrm{S}_{\mathrm{w}} / \mathrm{H}_{\mathrm{so}}=0.055-0.086
$$

Dunn (2001) studied wave setup in river entrances by using numerical, analytical and physical models in an attempt to explain the field data presented by Hanslow et al (1992 and 1996). One of the numerical modeling studies simulated the wave setup in a $330 \mathrm{ft}$ wide jetted river entrance by using Boussinesq model of Madsen et al (1997). The wave input data was generated by Jonswap spectrum with $\mathrm{H}_{\mathrm{so}}=10 \mathrm{ft}$ and peak period, $\mathrm{T}_{\mathrm{p}}=10$ second. Both the inlet dimension and wave input data are similar to the conditions at the Bolsa Chica Tidal Inlet. At a distance about $690 \mathrm{ft}$ (depth of $13 \mathrm{ft}$ ) landward from the end of jetty, which is the length of Bolsa Chica jetties, the model predicted wave setup is only $0.20 \mathrm{ft}$.

The Bolsa Chica tidal inlet is about $310 \mathrm{ft}$ wide and $5 \mathrm{ft}$ deep at MSL. The entrance channel is about $690 \mathrm{ft}$ long, and the spring tidal prism is about $96.4 \times 10^{6} \mathrm{ft}^{3}$. Compared to the Brunswick River entrance, the Bolsa Chica entrance is shallower and its tidal prism is smaller, which may lead to a relative smaller ebb bar and a higher wave setup than that at Brunswick River entrance. The wave setup in Shiribetsu River mouth is higher than that observed in Brunswick River entrance. The fresh water may contribute to the higher setup even though the fresh water discharge is low. For the Bolsa Chica tidal inlet, a median ratio of 0.07 between the wave setup and the offshore significant wave height was selected, and expressed as follow:

$$
\mathrm{S}_{\mathrm{wI}} / \mathrm{H}_{\mathrm{so}}=0.07
$$

In which $\mathrm{S}_{\mathrm{wI}}$ is the wave setup at the tidal entrance. The deep water wave height at a depth of $-50 \mathrm{ft}$ MSL under a 100-year storm event is $17.1 \mathrm{ft}$ (USACE 1996), the corresponding wave setup based on wave height is $1.20 \mathrm{ft}$. To be conservative, a wave setup of $1.30 \mathrm{ft}$ was added onto the extreme tidal elevation for the entrance and the PCH bridge design. Therefore, the ultimate design water level for jetties, bridges and shore protection was $+6.80 \mathrm{ft}$ MSL.

\section{Design Wave Parameters}

Jetty design requires consideration of the extreme wave conditions that can impinge upon the structure. Given the fact that the jetties terminate in fairly shallow water, the maximum wave that can break upon them will be limited by the maximum depth of water where the jetties are located. Waves larger than the depth-limited wave height break farther offshore. Determination of the maximum depth-limited breaking wave for jetty design must therefore consider the maximum water surface elevation and minimum bottom elevation. The design water level is $+6.80 \mathrm{ft}$, and the inlet depth is $-5 \mathrm{ft}$ MSL, therefore, the maximum water depth at the jetty entrance is $+11.80 \mathrm{ft}$. For the design wave with a period of 16 seconds, the ratio (Goda, 1985) is 0.882 . Therefore, the depth limiting breaker height is $10.4 \mathrm{ft}$. This wave height was used for the jetty design.

\section{Jetty Design}

The jetty design was iterated and optimized such that the jetties are relatively short and not designed to extend into the surf zone under most conditions, therefore they should not significantly interrupt sand transport, and should allow for sand movement to the down coast beach, but they are long enough to provide sufficient stabilization for the new inlet and to provide protection to the $\mathrm{PCH}$ Bridge by attenuating waves penetrating through the inlet. This is an effort to minimize or eliminate adverse effects to the shoreline. 
Jetty Length. Jetty length is particularly important, both in terms of project success and public acceptance. The jetty length should be short enough such that the potential for erosion of downdrift beaches is reduced. Short jetties are also desirable to reduce the resistance to tidal flow. Conversely, jetties should be long enough to accommodate storm, seasonal and long-term fluctuations in shoreline position. A key element of the preliminary engineering inlet studies (M\&N, 1999) was the assessment of jetty length and the associated impact on shoreline processes. The studies demonstrated that locating the seaward terminus of the jetties at the approximate mean lower low water (MLLW) depth contour resulted in minimal shoreline impacts relative to the other effects of wave modification and ebb/flood bar sedimentation. The referenced preliminary inlet studies identified an average MLLW depth contour to be located 445 feet and 420 feet from the seaward edge of Pacific Coast Highway at the north and south jetty locations, respectively. It is noted that any shoreline erosion identified to have been caused by jetty construction will be mitigated as part of the ongoing beach maintenance program.

Jetty Cross Sections. The elevation of the jetty crest was designed to be high enough to preclude significant volumes of sand to be transported over the jetties and into the tidal channel. Conversely, the jetty crest elevation was minimized to reduce aesthetic impacts and construction volumes. Experience has shown that setting the crest elevation just above the typical beach berm elevation will provide the desired performance with minimal impact. The preliminary engineering inlet studies identified an appropriate jetty crest elevation conforming to these guidelines is $+13 \mathrm{ft}$ MSL.

The toe of the jetty slope was constructed below the maximum wave- or current-induced scour depth. Historic beach profiles were reviewed and the toe of the jetty is located approximately $4.9 \mathrm{ft}$ below the deepest profile depth to provide a safety buffer against undermining.

The jetty structure slope is $2: 1(\mathrm{H}: \mathrm{V})$ throughout the full length until the transition to the interior dike design. This slope provides improved hydraulic performance than a steeper 1.5:1 slope, allowing greater stability of the critical section and allowing for a smaller stone size underneath the PCH Bridge which is desirable from a constructability standpoint. The jetty head and trunk sections were constructed with 10 and 8 tons of graded quarry stone layers based upon methods described in the Coastal Engineering Manual (2001).

\section{MONITORING RESULTS}

On August $24^{\text {th }}$ 2006, Bolsa Chica Wetlands was reconnected to the ocean after more than a century of separation, which also marked the completion of the two year construction. The monitoring program started immediately after the completion of the project and includes both the physical and ecological monitoring. The physical monitoring program is intended to monitor changes in relation to established management triggers, and to adaptively evaluate and recommend adjustment of triggers where appropriate to ensure the health of the system and protection of coastal beach resources (Merkel and Associate, Inc., 2008). This section focuses on the monitoring results of tidal responses and flood shoal development in the wetland basin.

\section{Inlet Flood Shoal Monitoring}

A newly formed or constructed inlet will interrupt longshore transport and divert sediment both offshore (creating an ebb bar) and towards the tidal basin (creating a flood shoal). As the ebb bar forms it will begin to affect the wave and current regime, which, in turn, causes the shoreline to deform. Eventually, the bar formation process will stabilize when the wave and current forces are in balance with the sediment transport regime. Similarly, the flood and ebb currents moving through the inlet will build and shape a flood shoal in the interior of the inlet. The rates of change within the ebb bar and flood shoal gradually diminishes as the conditions around the new inlet reaching the dynamic equilibrium. These bars can store large quantities of sediment, and their size, location and shape depend on the wetland tidal prism, inlet dimensions, lengths of the jetties, tidal range, sediment characteristics, offshore slope, nearshore wave climate and gross longshore sediment transport rate.

Ebb and Flood Shoal Study. Analytical modeling of the ebb bar and flood shoal growth was performed. The purpose of the work was to evaluate the growth rate and spatial distribution of both ebb bar and flood shoal. Results of this study were used for the Tidal Muting Study, Shoreline Morphology Study, and determining Maintenance Dredging Requirements (M\&N 1999). The predicted ebb bar and flood shoal volumes as well as annual shoaling rates are listed in Table 8 . The predicted flood shoal location is shown in Figure 7. To limit early adverse impacts of ebb bar development on the shoreline processes, approximately 1.2 million cubic yards (cy) of sand dredged from the FTB was discharged offshore to pre-fill ebb bar prior opening of the inlet. The fill was placed to avoid the potential for the full ebb bar developing from available beach sand engaged in longshore 
drift, thus robbing the littoral cell of mobile sand supply. The ebb placement was very successful since the beach monitoring results show that adjacent beach width variations have remained within the historic seasonal variations.

\begin{tabular}{|c|c|c|c|c|c|c|}
\hline \multirow[b]{2}{*}{ Time (yr) } & \multicolumn{2}{|l|}{ Ebb Bar } & \multicolumn{2}{|l|}{ Flood Shoal } & \multicolumn{2}{|l|}{ Total } \\
\hline & $\begin{array}{l}\text { Bar Volume } \\
\text { (cy) }\end{array}$ & $\begin{array}{l}\text { Shoaling } \\
\text { Rate (cy/yr) }\end{array}$ & $\begin{array}{l}\text { Shoal } \\
\text { Volume (cy) }\end{array}$ & $\begin{array}{l}\text { Shoaling Rate } \\
\text { (cy/yr) }\end{array}$ & $\begin{array}{l}\text { Bar Volume } \\
\text { (cy) }\end{array}$ & $\begin{array}{l}\text { Shoaling } \\
\text { Rate (cy/yr) }\end{array}$ \\
\hline 1 & 83,000 & 83,000 & 165,000 & 165,000 & 248,000 & 248,000 \\
\hline 2 & 174,000 & 92,000 & 299,000 & 134,000 & 473,000 & 226,000 \\
\hline 3 & 283,000 & 109,000 & 363,000 & 64,000 & 646,000 & 173,000 \\
\hline 4 & 400,000 & 116,000 & 373,000 & 10,000 & 773,000 & 126,000 \\
\hline 5 & 497,000 & 97,000 & 374,000 & 1,000 & 871,000 & 98,000 \\
\hline 10 & 622,000 & 2,000 & 374,000 & 0 & 996,000 & 2,000 \\
\hline
\end{tabular}

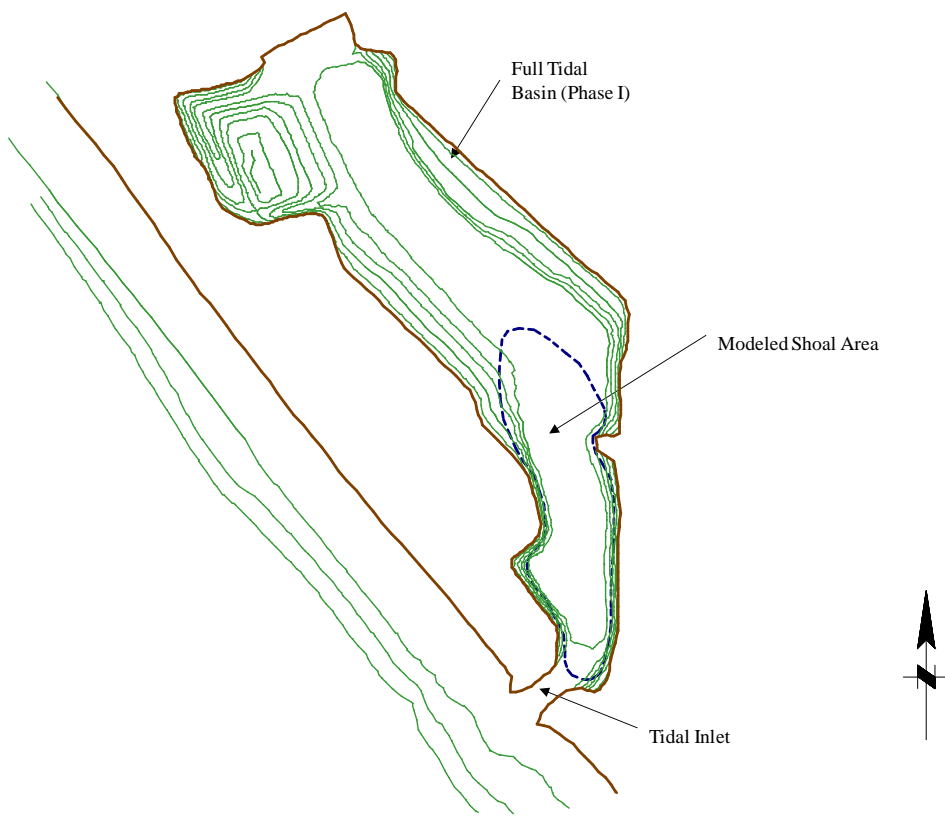

Figure 7. Modeled Flood Shoal Area for Phase I Project Condition

As the flood shoal develops, it will begin to restrict tidal flows through the inlet. Tidal flow restrictions will mute the tidal range in the wetland system relative to the tidal range that would achieve without the flood shoal. Therefore, a monitoring, maintenance and maintenance dredging program was incorporated into the wetlands restoration project. The preliminary engineering study (M\&N 1999) indicated that the flood bar would need to be managed by dredging every two years and placement of the dredged sand on the downcoast beach or the beach location of greatest need. This sand management program will maintain the downcoast sediment supply over the long term and should not cause shoreline changes beyond the seasonal variations before the project.

Monitoring Results. The rate and spatial distribution of sand accumulation in the FTB has been assessed during the first two monitoring years on January 19, 2007, June 27, 2007; January10, 2008, and July 1, 2008. A survey was also conducted on December 23, 2008 to document the pre-dredge bathymetry condition prior to the first episode of the flood shoal maintenance dredging, which occurred in early 2009 as anticipated. The bathymetry surveys within the FTB were compared to the bathymetry condition prior to the opening of the inlet and accumulative sediment accretions in the FTB were then calculated. Their results are presented in Table 9. As anticipated, there was a large input of sand between the inlet opening and the first survey on January 19, 2007, and the shoaling rate gradually reduced as the flood shoal develops toward a dynamic equilibrium state. A grain size analyses of the sand accreted in the FTB was conducted in June 2008 in anticipation of the maintenance dredging activity. The shoal sediment is composed entirely of littoral sand. Based on the bathymetry surveys, the estimated flood shoal volume deposited in the FTB during the first year postopening was approximately $166,667 \mathrm{cy}$, which is only $1 \%$ higher than the 165,000 cy predicted as the 
first year shoal volume listed in Table 8. The survey based second year shoaling volume is 69,400 cy, which is smaller than the model predicted volume of 134,000 cy. However, the model predicted twoyear accumulative shoal volume of 299,000 cy compares favorably to the measurement of 237,000 cy shoal volume.

Overall, the flood shoal volume, area of shoaling and shoaling rate have all occurred similarly to processes predicted during the preliminary engineering study and the project design.

\begin{tabular}{|c|c|c|c|c|c|c|}
\hline Survey Date & $08 / 2006$ & $01 / 2007$ & $06 / 2007$ & $01 / 2008$ & $07 / 2008$ & $12 / 2008$ \\
\hline Net Accretion (cy) & 0 & 78,000 & 160,000 & 207,000 & 237,000 & 268,000 \\
\hline Shoaling Rate (cy/day) & $\mathrm{n} / \mathrm{a}$ & 526 & 364 & 238 & 166 & 186 \\
\hline
\end{tabular}

\section{Tidal Monitoring}

Tidal monitoring is fundamental to understand the tidal muting, lag and inundation frequency in the FTB. Tides at the FTB have been continuously monitored at a 6 minute interval since December 21, 2007. The tidal data were collected with an RBR Instruments TGR 2050 pressure gage. Recorded tides were compared with tides measured at the nearest tide station at the LAOH. The results indicate that high tides are not muted as predicted, however, the lower low tides are muted, especially the spring low tides since it takes a longer time for the basin to drain during the spring tidal cycle. The spring low tide muting is plotted in Figure 8. The average spring low tide muting under the postconstruction condition predicted by the RMA2 model was $0.9 \mathrm{ft}$, which is well within these measured over the first couple of months of monitoring. The spring low tide lag in January 2007 was 1.3 hours which is also similar to the model prediction of 1.5 hours. However, the spring low tide muting were more than model predicted under the muted condition with the flood shoal development in the FTB.

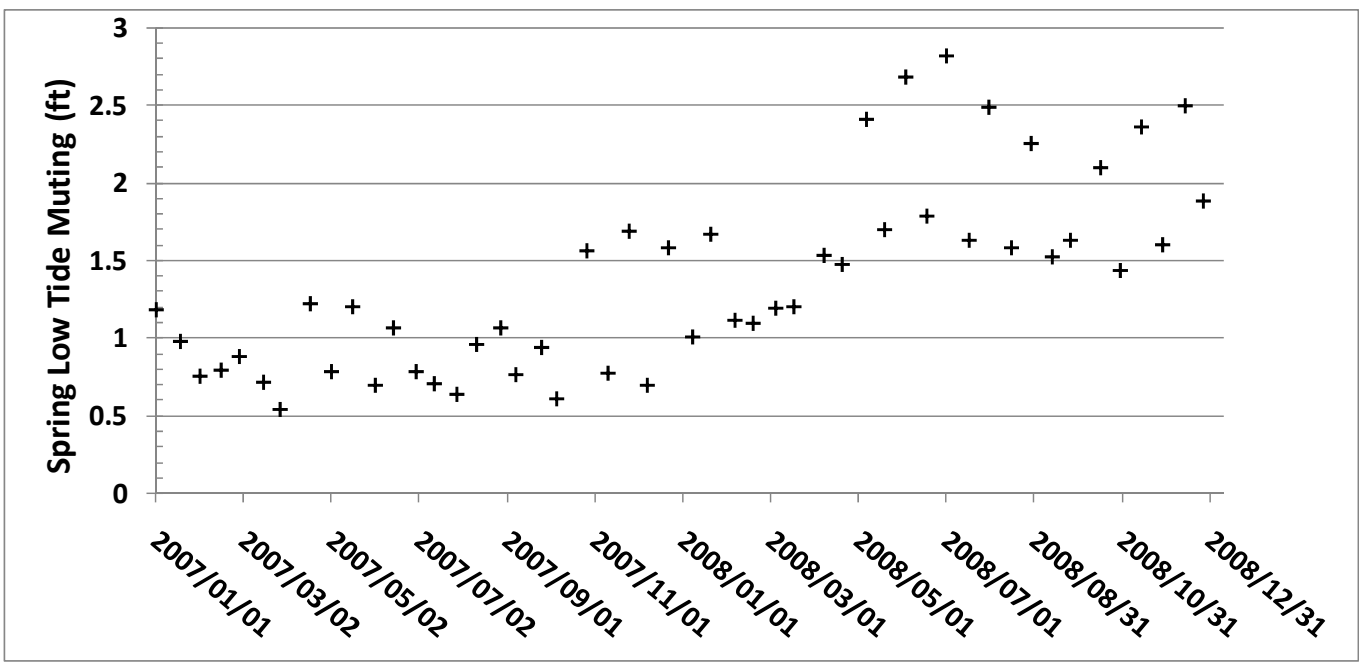

Figure 8. Spring Low Tide Muting in FTB

\section{ACKNOWLEDGMENTS}

We would like to thank and acknowledge the Bolsa Chica Steering Committee, made up of representatives of the eight agencies involved in the management and oversight of the project development. In particular, we wish to acknowledge the California Coastal Conservancy, U.S. Fish and Wildlife Service and the California State Lands Commission, under whose contracts the various phases of the project were undertaken.

\section{REFERENCES}

Barnett, J.H. 1984. The Estimation of “Global” Sea Level Change: A Problem of Uniqueness, Journal of Geophysical Research, 89 (C5) pp.7980-7988. 
Bruun, P., Mehta, A.J., and Johnson, I.G. 1978. Stability of Tidal Inlet, Elsevier Scientific Publishing Company, Amsterdam, pp. 510, 1978.

Douglas, B.C., M.S. Kearney, and S.P. Leatherman. 2001.Sea Level Rise: History and Consequences, Academic Press, San Diego.

U.S. Environmental Protection Agency. 1983. Projecting Future Sea Level Rise, Washington D.C.

Escoffier, F.F. 1940. The Stability of Tidal Inlets. Shore and Beach, 8 (4), pp. 114-115.

Flick, R.E. and D.C. Cayan. 1984. Extreme Sea Levels on the Coast of California, Proceedings $19^{\text {th }}$ International Conference Coastal Engineering, American Society of Civil Engineers, p. 886-898.

Flick, R.E. and A. Badan-Dangon. 1989. Coastal Sea Levels During the January 1988 Storm off the Californias, Shore \& Beach, 57(4), 28-31.

Flick, R.E. 1998. Comparison of California Tides, Storm Surges, and Mean Sea Level During the California El Nino Winters of 1982-83 and 1997-98, Shore and Beach, v.66, n. 3.

Goda, Y. 1985. Random Seas and Design of Maritime Structures, University of Tokyo Press, Japan.

Gornitz, V.S., S. Lebedeff, and J. Hansen. 1982. Global Sea Level Trend in The Past Century, Science, 215, pp.1611-1614.

Hanslow, D.J., and P. Nielsen 1992. Wave Setup on Beaches and in River Entrances, Proc. 23 ${ }^{\text {rd }}$ International Conference of Coastal Engineering, Venice, pp.240-252.

Hanslow, D.J. et al. 1996. Wave Setup at River Entrances, Proc. $25^{\text {rd }}$ International Conference of Coastal Engineering, Orlando, pp.2244-2257.

Intergovernmental Panel on Climate Change (IPCC). 1990. Scientific Assessment of Climate Change, Blacknell, UK, UK Meteorological Office.

Jarrett, J.T. 1976. Tidal Prism - Inlet Area Relationships, General Investigation of Tidal Inlets - GITI Report 3, Department of the Army, Corps of Engineers.

Madsen, et al. 1997. Surf Zone Hydrodynamics Simulated by A Boussinesq Type Model, Part 1: Model Description and Cross-shore Motion of Regular Waves, Coastal Engineering, 32, pp.255288.

Meier, M.F. 1984. Contribution of Small Glaciers to Global Sea Level, Science, 168, pp1418-1421.

Meier, M.F. 1990. Reduced Rise in Sea Level, Nature 343, p.115.

Merkel and Associates, Inc. 2008. Bolsa Chica Wetlands Restoration Project, Monitoring Program.

Moffatt \& Nichol. 1999. Preliminary Engineering Studies for Bolsa Chica Wetlands Restoration, Final Report. Prepared for California State Coastal Conservancy.

Moser, S. 2003. Impacts of Climate Change in the United States-California, http://www.climatehotmap.org/impacts/california.html.

National Oceanic and Atmospheric Administration, National Ocean Service (NOAA/NOS). 1997. http://co-ops.noss.gov/seatrnds.html.

O’Brien, M.P. 1969. Equilibrium Flow Areas of Inlets on Sandy Coasts. Journal of Waterway and Harbour Division, ASCE, 95, WW1, 43-52.

Peltier, W.R., and A.M. Tushingham. 1989. Global Sea Level Rise and The Greenhouse Effect: Might They Be Connected? Science, 244, pp. 806-810.

Tanaka, H. and H. Lee. 2001. Relationship Between River Mouth Morphology and Wave Setup Height at Shiribetsu River, Japan. $2^{\text {nd }}$ IAHR Symposium on River Coastal and Estuarine Morphodynamics, Obihiro, Japan, pp. 495-504.

U.S. Army Corps of Engineers. April 1993. Existing State of Orange County Coast, Coast of California Storm and Tidal Waves Study South Coast Region, Orange County.

U.S. Army Corps of Engineers. 1996. Nearshore Hydrodynamic Factors and Wave Study of the Orange County Coast, Coast of California Storm and Tidal Wave Study, South Coast Region.

U.S. Army Corps of Engineers. 2001. Coastal Engineering Manual.

U.S. Geological Survey. 1999. El Nino Sea-Level Rise Wreaks Havoc in California’s San Francisco Bay Region, USGS Fact Sheet 175-99.

Van de Kreeke, J. 1984. Residence Time: Application of Small Boat Basins, Journal of Waterways, Port, Coastal, and Ocean Engineering, ASCE, Vol. 109, No. 4, pp. 416-428. 